\title{
KS. PROF. WALERIAN MEYSZTOWICZ I POLSKI INSTYTUT HISTORYCZNY W RZYMIE
}

\author{
Mirosław A. SUPRUNIUK (Toruń)
}

Działający w latach 1919-1939 w Wilnie, na północnych kresach Drugiej Rzeczypospolitej, polski Uniwersytet Stefana Batorego (USB), powstał jako kontynuacja tradycji Uniwersytetu Wileńskiego z lat 1579-1832. Był jednym z pięciu polskich państwowych uniwersytetów w latach międzywojennych i jedynym, który kształcił w niemal wszystkich dziedzinach nauki: od literaturoznawstwa po matematykę i astronomię, od prawa po medycynę i stomatologię, od sztuk pięknych po rolnictwo. Przy USB działał najważniejszy w Europie instytut sowietologiczny - Instytut Europy Wschodniej. We wrześniu 1939 roku Wilno zostało zajęte przez wojska sowieckie, a w końcu października przekazane Republice Litewskiej. W grudniu tego roku, rząd litewski zamknął USB, powołując w jego miejsce uniwersytet litewski. Pracownicy polskiego uniwersytetu utracili pracę, a często także wolność, gdy wojska sowieckie wiosną roku 1940 ponownie wkroczyły do Wilna. Aresztowania i zsyłki w głąb Związku Sowieckiego dotknęły najwybitniejszych profesorów Almae Matris Vilnensis; wielu z tych, którzy przeżyli, nigdy nie powróciło do Polski.

Losy profesorów, pracowników i wychowanków Uniwersytetu Stefana Batorego, którzy w wyniku drugiej wojny światowej znaleźli się na emigracji, nie były do tej pory tematem większej publikacji naukowej. Wyjątek stanowi ogromna pisarska spuścizna Czesława Miłosza, wychowanka wileńskiego uniwersytetu, oraz wielka liczba publikacji poświęconych poecie, który w konsekwencji wyborów podejmowanych po roku 1945 został profesorem literatury rosyjskiej i polskiej na Uniwersytecie Kalifornijskim w Berkeley. Wszelako, nie licząc kilku słowników biograficznych, leksykonów i encyklopedii, w których pojawiły się hasła i życiorysy innych wilnian i - jak to często określano na emigracji — „uesbistów”" , oraz tekstów traktujących o organiza-

\footnotetext{
${ }^{1}$ Wśród najwybitniejszych ludzi nauki wywodzących się z Wilna wymienić należy: Stani-
} 
cjach, stowarzyszeniach i wydarzeniach politycznych z udziałem wilnian, na uwage zasługuje zaledwie kilka artykułów i nieliczne książki ${ }^{2}$. Owe większe publikacje zwarte to: korespondencja Czesława Miłosza z Manfredem Kridlem, profesorem literatury na $\mathrm{USB}^{3}$ i próba monografii dorobku tego literaturoznawcy ${ }^{4}$, biografia Mariana BohuszaSzyszko, malarza, wychowanka Uniwersytetu ${ }^{5}$, szkic na temat religijności Stanisława Kościałkowskiego ${ }^{6}$ oraz artykuł i książka poświęcone Stanisławowi Swianiewiczowi ${ }^{7}$. Warto zauważyć, że M. Kridl spośród wymienionych doczekał się w ostatnich latach bodaj największej liczby publikacji na swój temat, w szczególności dotyczących okresu emigracyjnego jego życia i działalności ${ }^{8}$. Wśród tekstów cząstkowych na uwagę zasługują hasła w Leksykonie kultury polskiej poza krajem od roku 1939, którego pierwszy i jedyny tom ukazał się w Lublinie w 2000 roku pod redakcją Krzysztofa Dybciaka i Zdzisława Kudelskiego. Należy też zwrócić uwagę na teksty traktujące o działalności stowarzyszeń zrzeszających liczne grono kadry i wychowanków USB: Związku Ziem Północno-Wschodnich oraz Społeczności Akademickiej USB w Londynie?. Opisujący

sława Kościałkowskiego (historyk), ks. Waleriana Meysztowicza (teolog i historyk), Manfreda Kridla (literaturoznawca), Wacława Komarnickiego (historyk prawa), Wiktora Sukiennickiego (historyk), Cezarię Jędrzejewiczową (etnolog), Stanisława Swianiewicza (historyk, politolog), Lucjana Turkowskiego (etnolog), Józefa Bujnowskiego (literaturoznawca), Józefa Trypućko (językoznawca, bibliograf), Aleksandra Bluma (historyk), Jana Kruszyńskiego (medyk), Halinę Sukiennicką (prawniczka, malarka), Stefana Glasera (prawnik), Zbigniewa Folejewskiego (literaturoznawca i językoznawca), Bogumiła Jasinowskiego (historyk filozofii), Jerzego Aleksandrowicza (biolog), Jana Wilczyńskiego (biolog) i Leopolda Kielanowskiego (teatrolog).

${ }^{2}$ Np. szkic Józefa Długosza Stanisław Kościałkowski (1881-1960) uczony i patriota, [w:] Wilno - Wileńszczyzna jako krajobraz i środowisko wielu kultur, t. 3, Białystok 1992, s. 59-70, który nie wychodzi poza ustalenia Leonida Żytkowicza, autora hasła w PSB.

${ }^{3}$ Cz. Miłosz, ,, Mój wileński opiekun”. Listy do Manfreda Kridla (1946-1955), z uzupełnieniem o listy Manfreda Kridla i addendum. $Z$ autografu do druku przygotował, słowem wstępnym, przypisami i notą edytorską opatrzył A. Karcz, Toruń 2005.

${ }^{4}$ S. Kitab, Teoria Manfreda Kridla: próba uzupetnienia metody integralnej, Torun 2000.

${ }^{5}$ J. W. Sienkiewicz, Marian Bohusz-Szyszko: życie i twórczość 1901-1995, Lublin 1996.

${ }^{6}$ K. Stachewicz, Stanisława Kościatkowskiego droga do prawdy. Refleksje inspirowane ksiązka ,, Via lucis”, Archiwum Emigracji. Studia - Szkice - Dokumenty 2002/2003 z. 5/6, s. 7-21.

${ }^{7}$ I. Hofman, Publicystyka społeczno-polityczna Stanistawa Swianiewicza, [w:] Powrześniowa emigracja niepodległościowa na mapie kultury nie tylko polskiej: Paryż-LondynMonachium-Nowy Jork, red. V. Wejs-Milewska i E. Rogalewska, Białystok 2009, s. 373-388; Stanisław Swianiewicz (1899-1997): ekonomista, sowietolog, historyk, red. B. Gaziński, Olsztyn 2010 .

${ }^{8}$ E. Kridl Valkenier, Manfred Kridl: uczony, pedagog, działacz polityczny, [w:] Wilno $i$ świat. Dzieje środowiska intelektualnego, t. 2, red. E. Feliksiak i M. Leś, Białystok 2002, s. 927; A. F. Kola, ,Obdarowuje Pan nas tutaj ciagle...”. Manfreda Kridla pomoc dla Uniwersytetu Mikołaja Kopernika $w$ Toruniu, Archiwum Emigracji 2010 z. 1-2 (12-13), s. 103-136; A. Karcz, ,Znosić wygnanie $w$ tym pięknym,... ale jakże obcym kraju” — lata amerykańskie Manfreda Kridla, Archiwum Emigracji 2002/2003 z. 5/6, s. 23-37; tenże, Teksty z daleka i bliska: szkice nie tylko o literaturze, Kielce 2003.

${ }^{9}$ P. Wójtowicz, Działalność Zwiazków Ziem Wschodnich w Londynie w latach 1942-1955, [w:] Przeszłość, teraźniejszość i przyszłość Polaków na Wschodzie, red. M. Szczerbiński i T. Wolsza, Gorzów Wielkopolski 2001; M. A. Supruniuk, Losy profesorów Uniwersytetu Stefana Batorego po 1945 roku: Społeczność Akademicka U.S.B. na Obczyźnie (1947-1987), [w:] 60-lecie Uniwersytetu Mikołaja Kopernika w Toruniu, red. Cz. Łapicz i W. Wróblewski, Toruń 2006. O działalność „uesbistów” w latach wojny zahaczają teksty Krystyny Jaworskiej, Wileńszczyzna w wydawnictwach i wspomnieniach żotnierzy Drugiego Korpusu, [w:] Wilno - Wileńsz- 
dorobek polskiej historiografii na uchodźstwie w Wielkiej Brytanii Rafał Stobiecki, Społeczności wraz z jej publikacjami i działalnością odczytową poświęcił zaledwie dwie strony, osobno omawiając publikacje jej członków ${ }^{10}$. Z obowiązku rzetelności, odnotować należy również kilka tekstów powstałych w Polsce w latach 40., które dotyczyły działalności wilnian na Bliskim i Środkowym Wschodzie ${ }^{11}$ oraz cenne opracowanie na ten temat Jana Drausa ${ }^{12}$.

Niezwykle rzadko dokonywano przedruków prac profesorów USB, powstałych jeszcze w Wilnie lub, co jeszcze rzadsze, wydanych na emigracji. Przed rokiem 1990 było to niemal sporadyczne. W niewielkim stopniu lukę tę uzupełnił tzw. drugi obieg wydawniczy; poza obiegiem cenzury ukazały się książki i fragmenty opracowań Władysława Wielhorskiego, Wiktora Sukiennickiego i Stanisława Swianiewicza ${ }^{13}$. Naturalnie, w publikacjach okolicznościowych i prasie wydawanej po 1990 roku przez wszelkiego rodzaju stowarzyszenia wilnian i Kresowian przedrukowywane były fragmenty opracowań na temat Uniwersytetu Stefana Batorego, teksty wspomnieniowe i biografie, lecz ze względu na nienaukowy charakter tych przedruków nie bierzemy ich pod uwagę. Zdaje się, że - nie licząc prac wspomnieniowych Stanisława Swianiewicza: W cieniu Katynia oraz Dzieciństwo i młodość, a także Waleriana Meysztowicza Gawędy o czasach i ludziach, a także kilku publikacji w tzw. drugim obiegu lat 1976-1989, można tu przytoczyć jedynie pięć książek wydanych w Polsce w naukowym opracowaniu; trzy są pracami Wacława Komarnickiego i po jednej: Cezarii Jędrzejewiczowej i Stanisława Kościałkowskiego. Były to: Wacław Komarnicki o ustroju państwa i konstytucji, ze wstępem i w wyborze Stanisława Kiliana (Warszawa 2000), W. Komarnicki, Polskie prawo polityczne (geneza i system) (Warszawa 2008) — obie wydane przez

czyzna jako krajobraz i środowisko wielu kultur, t. 4, Białystok 1992, s. 425-426 oraz Pawła Gotowieckiego, Działalność żolnierzy II Korpusu Polskiego w zwiazkach ziem wschodnich i innych środowiskach kresowych na emigracji, [w:] II Korpus Polski w kampanii wrześniowej i losy jego żotnierzy po wojnie, red. J. Smoliński, K. Piwowarska, Warszawa 2008, s. 74-95. Odnotować dla porządku należy też tekst: M. B. Topolska, Uczeni emigracyjni po $1945 \mathrm{r}$. jako kontynuatorzy historiografii ziem wschodnich $w$ dziejach Rzeczypospolitej, [w:] Materiaty V Sympozjum Biografistyki Polonijnej, Kraków, 22-23 września 2000, red. A. Judycka i B. Klimaszewski, Lublin 2000, s. 259-266, który nie wnosi niczego nowego do dyskursu.

${ }^{10}$ R. Stobiecki, Klio na wygnaniu. Z dziejów polskiej historiografii na uchodźstwie $w$ Wielkiej Brytanii po 1945 r., Poznań 2005, s. 92-93.

${ }^{11}$ F. Machalski, Działalność Towarzystwa Studiów Irańskich w Teheranie (1942-1945) i Instytutu Polskiego w Bejrucie (1945-1947), Życie Nauki 1948 t. 7 nr 33-34, s. 257-262; W. Zajączkowski, Polska działalność orientalistyczna na Wschodzie w latach 1942-1946, Przegląd Orientalistyczny 1948 (druk: 1949) z. 1, s. 91-94; M. Dunajówna, Polskie wydawnictwa w Iranie w okresie ostatniej wojny, Bibliotekarz 1947 nr 9-10, s. 148-149.

12 J. Draus, Oświata i nauka polska na Bliskim i Środkowym Wschodzie 1939-1950, Lublin 1993.

${ }^{13} \mathrm{~W}$. Wielhorski, Trzy pytania i trzy odpowiedzi. (Prawda o deportacji Polaków pod panowaniem sowieckim), Kraków: [Wydawnictwo] Kraków, 1986, okł. kart., [2], 36, [1] s., powiel., A-5; tenże, Wspomnienia z przeżyć w niewoli sowieckiej, Łódź, Poznań, Torun, Wrocław: TON Towarzystwo Oświaty Niezależnej, b.r. [1985], okł. kart., skrzydeł., [11], 10-140, [3] s., off. z oryg., A-6; S. Swianiewicz, Lenin jako ekonomista, Poznań: Wyd[awnictwo] Głosy, 1983, 15, [1] s., off. z masz., A-6; W. Sukiennicki, Pót wieku sowieckiej „,rewolucji”, [Szczecin]: Studencka Agencja Wydawnicza SAW im. Uniwersytetu Zachodnio-Pomorskiego, [1981], okł., 45, [1] s., off. z oryg., A-6; tenże, Pól wieku sowieckiej „rewolucji”, [Kraków]: Wydawnictwo „V” 1984, [2], 45, [1] s., off. z oryg., A-6. Niewielka liczba tekstów ukazała się również w nieocenzurowanej prasie; patrz: J. Kandziora, Z. Szymańska, Bez cenzury 1976-1989: literatura, ruch wydawniczy, teatr: bibliografia, Warszawa 1999. 
Wydawnictwo Sejmowe, oraz tegoż: Ustrój państwowy Polski współczesnej. Geneza i system, w reprincie Wydawnictwa UJ (Kraków 2006), a także: Akty cechów wileńskich 1495-1759, zebrał i przygotował do druku Henryk Łowmiański przy współudziale Marii Łowmiańskiej i Stanisława Kościałkowskiego (Poznań 2006) i wreszcie Łańcuch tradycji: teksty wybrane Cezarii Baudouin de Courtenay-EhrenkreutzJędrzejewiczowej, w wyborze Lecha Mroza i Anny Zadrożyńskiej (Warszawa 2005). Z obowiązku bibliografa dodać wypadnie jeszcze szkice Mariana Bohusza-Szyszko przedrukowane w tomie Sztuka polska w Wielkiej Brytanii 1940-2000 (Toruń 2006), niewielkie artykuły S. Kościałkowskiego z okresu wojennego, przedrukowane w tomie Polacy $w$ Iranie 1942-1945, tom 1 w opracowaniu Andrzeja K. Kunerta (Warszawa 2002), oraz fotografie zamieszczone w monografii ikonograficznej Uniwersytetu Stefana Batorego ${ }^{14}$. Casus profesora USB, wybitnego matematyka Antoniego Zygmunta, który od 1940 roku wykładał w Massachusetts Institute of Techology i na innych uniwersytetach amerykańskich, a jego prace przedrukowywane były w Polsce, jest trudny do opisania i wymaga osobnego studium. Zaznaczmy tu jedynie, że w podobnej sytuacji był również prof. Manfred Kridl, którego niektóre prace ukazały się przed 1989 rokiem w Polsce.

W środowisku historyków polskich na emigracji ludzie nauki wywodzący się z Wilna, a w szczególności z Uniwersytetu Stefana Batorego, stanowili znaczącą grupę. Wśród nich postacią przez wszystkich Wilnian uważaną za najwybitniejszą był Stanisław Kościałkowski (1881-1960), historyk, nauczyciel akademicki; członek tajnego Komitetu Organizacyjnego Uniwersytetu Wileńskiego w roku 1918, a od 1919 zastępca profesora (później profesor, 1922) historii Polski USB. Współtwórca „Ateneum Wileńskiego". W latach 1939-1941 brał udział w tajnym nauczaniu w Wilnie. W 1941 roku aresztowany i zesłany w głąb Związku Sowieckiego; uwolniony w wyniku umowy Majski-Sikorski, został w 1942 roku ewakuowany do Iranu, gdzie pozostał do 1945 roku, współtworząc instytut naukowy pod nazwą Towarzystwo Studiów Irańskich. Następnie przeniósł się do Bejrutu, gdzie został organizatorem i dyrektorem Instytutu Polskiego. W 1950 roku wyjechał się do Londynu, gdzie został wykładowcą Polskiego Uniwersytetu na Obczyźnie. Kościałkowski był autorem monumentalnej biografii Antoniego Tyzenhauza (Londyn 1970/1971), do której materiał zbierał od końca XIX wieku. Opublikował m.in.: Za studiów nad dziejami ekonomij królewskich na Litwie (1915); Z dziejów Komisji Skarbowej Litewskiej (1924); Historyka. Wstęp do studiów historycznych $(1954)^{15}$.

Kilka lat młodszym od S. Kościałkowskiego był prof. Władysław Wielhorski (1885-1967), ekonomista, politolog i historyk Wielkiego Księstwa Litewskiego. Od roku 1930 był dyrektorem związanego z USB Instytutu Naukowo-Badawczego Europy Wschodniej w Wilnie i dyrektorem Szkoły Nauk Politycznych przy tym Instytucie (od 1931). Był też posłem na Sejm (1935-1939). W pracy naukowej zajmował się Litwą i tematyką stosunków polsko-litewskich, po wojnie na emigracji w Wielkiej Brytanii, napisał m.in.: Polska a Litwa. Stosunki wzajemne w biegu dziejów (1947), Ustrój agrarny ZSRR (1949) ${ }^{16}$.

${ }^{14}$ A. Supruniuk, M. A. Supruniuk, Uniwersytet Stefana Batorego w Wilnie 1919-1939 w fotografiach, Toruń 2009.

${ }^{15}$ Por.: M. Filipowicz, Kościałkowski Stanistaw, [hasło w:] Leksykon kultury polskiej poza krajem od roku 1939, t. 1, Lublin 2000, s. 194-195.

${ }^{16}$ Patrz: S. Mękarski, Ś.p. Władysław Wielhorski, Rocznik Polskiego Towarzystwa Naukowego na Obczyźnie 1967 t. 17, s. 27-28. 
Wśród historyków młodszych, absolwentów i wychowanków Uniwersytetu w Wilnie, byli: Stanisław Swianiewicz (1899-1997), historyk prawa, sowietolog, ekonomista, w latach 1924-1939 wykładowca i profesor ekonomii politycznej na USB i w Szkole Nauk Politycznych. Więzień obozu w Kozielsku (1939-1941), uwolniony wydostał się na Bliski Wschód. Po wojnie osiadł w Londynie; pracował jako wykładowca w szkołach wyższych; wykładał również w Indonezji, USA i Kanadzie. Opublikował m.in.: Polityka gospodarcza Niemiec hitlerowskich (1938), Forced Labour and Economic Development (1965) oraz W cieniu Katynia (1976) ${ }^{17}$. A także Wiktor Sukiennicki (1901-1983), historyk prawa, politolog, ekonomista, od roku 1931 zastępca profesora na USB oraz kierownik działu prawno-politycznego Instytutu Naukowo-Badawczego Europy Wschodniej w Wilnie. W latach wojny prowadził w Wilnie tajne wykłady dla studentów. W połowie czerwca 1941 roku aresztowany przez NKWD i zesłany do obozu w Kraju Krasnojarskim. Zwolniony w wyniku amnestii od stycznia do września 1942 roku pracował w Ambasadzie RP w Kujbyszewie. W końcu 1942 roku wyjechał do Teheranu, gdzie wespół ze S. Kościałkowskim założyli Towarzystwo Studiów Irańskich i czasopismo „Studia Irańskie” (1943-1945). W 1943 roku dotarł do Londynu i podjął wykłady na Polskim Wydziale Prawa na Uniwersytecie Oksfordzkim, które prowadził do roku 1947. Był współzałożycielem i wykładowcą Szkoły Nauk Politycznych i Społecznych w Londynie. Opublikował: Wspótczesne idee polityczne i społeczne (1951) i Współczesne ruchy polityczne i społeczne (1954). W 1959 roku wyjechał do Stanów Zjednoczonych, gdzie rozpoczął badania w Instytucie Hoovera przy Uniwersytecie Stanforda nad dziejami Europy Wschodniej. Efektem studiów była dwutomowa publikacja East Central Europe in War World I. From Foreign Domination to National Freedom (1984). Współpracował z Instytutem Literackim w Paryżu, w którym ogłosił trzy prace, w tym wspomnienia z Wilna Legenda i rzeczywistość: wspomnienia i uwagi o dwudziestu latach Uniwersytetu Stefana Batorego w Wilnie (Paryż 1967) oraz Biała księgę: fakty i dokumenty z okresów dwóch wojen światowych (Paryż 1964) ${ }^{18}$.

Ze środowiskiem historyków związana była także Cezaria Baudouin de Courtenay Ehrenkreutzowa Jędrzejewiczowa (1885-1967), etnolog, prof. i kierownik Zakładu Etnologii USB w Wilnie (1922-1934) i Szkoły Nauk Politycznych tamże, współpracownik Komisji Etnograficznej PAU. Założyła Muzeum Etnograficzne na USB. Opublikowała w tym okresie m.in.: Ze studiów nad obrzędami weselnymi ludu polskiego (1929). W latach wojny przebywała w Palestynie, a w 1947 roku dotarła do Londynu. Współorganizowała tam Polskie Towarzystwo Naukowe na Obczyźnie. Była także współtwórcą Polskiego Uniwersytetu na Obczyźnie, a od 1959 do 1967 roku rektorem tej uczelni. Była ponadto członkiem Towarzystwa Historyczno-Literackiego w Paryżu oraz Royal Anthropological Institute of Great Britain and Ireland. Na emigracji opublikowała m.in.: Etnografia ziemi wileńskiej. Grupy etniczne na ziemiach W. Ks. Litewskiego i trzy narody $(1953)^{19}$.

${ }^{17}$ Zob.: Stanisław Swianiewicz (1899-1997): ekonomista, sowietolog, historyk, red. B. Gaziński, Olsztyn 2010.

${ }^{18}$ Zob.: R. Habielski, Sukiennicki Wiktor, [hasło w:] Leksykon kultury polskiej poza krajem od roku 1939, t. 1, Lublin 2000, s. 420-423; M. Kornat, Sukiennicki Wiktor (1901-1983), PSB z. 186, Warszawa 2008, s. 396-401.

${ }^{19}$ Zob.: Śp. Cezaria Baudouin de Courtenay Jędrzejewiczowa, Rocznik Polskiego Towarzystwa Naukowego na Obczyźnie 1967 t. 17, s. 19-21; J. Draus, Życie i działalność Cezarii Baudouin de Courtenay-Jędrzejowiczowej (1885-1967), [w:] Losy Polek żyjących na obczyźnie i ich wktad w kulturę i naukę świata. Historia i wspótczesność, red. A. Judycka, Z. Judycki, Lublin 1999. 
W kontekście dorobku historyków polskich wywodzących się z Wilna i związanych z Uniwersytetem Stefana Batorego, na szczególną uwagę zasługuje dorobek ks. prof. Waleriana Meysztowicza.

\section{Ksiądz profesor Walerian Meysztowicz — wilnianin}

W 1932 roku ks. Walerian Meysztowicz, absolwent Uniwersytetu Stefana Batorego w Wilnie i Papieskiego Instytutu Apolinaris w Rzymie, profesor wileńskiego Seminarium Duchownego i wykładowca prawa kanonicznego na Wydziale Teologicznym USB, został mianowany radcą kanonicznym (prawnym) w Ambasadzie Rzeczypospolitej Polskiej w Watykanie, przy ambasadorze Władysławie Skrzyńskim. Okoliczności tego mianowania, a także samego wyjazdu, opisał Stanisław Mackiewicz w artykule Mise au point, w 1959 roku $^{20}$. Praca w służbie dyplomatycznej, możliwość studiowania archiwów kościelnych, a także narzucona dyscyplina, pozwoliły mu ukończyć w niespełna dwa lata publikację naukową Dobra kościelne jako przedmiot uprawnień w prawie Wielkiego Księstwa Litewskiego (Wilno 1935). W 1936 roku już jako prałat papieski (1934), ks. Meysztowicz został mianowany profesorem prawa kanonicznego na Wydziale Teologicznym Uniwersytetu Wileńskiego. Nie zrezygnował z pracy radcy prawnego w ambasadzie, łącząc oba stanowiska aż do grudnia 1939 roku, tj. rozwiązania USB.

W 1940 roku Meysztowicz, z Wilna przez Kowno, Szwecję i Anglię, wrócił do Rzymu i przez cały okres wojny, wraz a ambasadorem Kazimierzem Papée, przebywał w Watykanie, poświęcając wiele czasu na studia w Bibliotece i Archiwum Watykańskim, współpracując jednocześnie z przedstawicielem rządu RP na Uchodźstwie w Rzymie, Stanisławem L. Janikowskim, który w tym samym czasie pisał książkę o Mikołaju Koperniku ${ }^{21}$.

W roku 1940 w Rzymie ks. Meysztowicz, zakładając tymczasowość sytuacji, która wytworzyła się po zajęciu Wilna przez władze litewskie i likwidacji USB, i w przekonaniu o konieczności kontynuowania uniwersyteckiej działalności naukowej, powołał w Rzymie swego rodzaju emigracyjny „Instytut Teologiczny USB” i kontynuował działalność wydawniczą prowadzonej w Wilnie serii „Studia Teologiczne”.

Ukazujące się w Wilnie na Wydziale Teologicznym od 1932 roku pod redakcją ks. Czesława Falkowskiego „Studia”, publikowały głównie rozprawy akademickie pracowników wydziału. Do roku 1939 ukazało się dziesięć tomów, wśród nich wspomniana wyżej dysertacja ks. Meysztowicza ${ }^{22}$.

${ }^{20}$ S. Mackiewicz, Mise au point, Kultura $1959 \mathrm{nr} 4$ (138) s. 119.

${ }^{21}$ W. Meysztowicz, Gawędy o czasach i ludziach. Wyd. 4, Londyn 1993, s. 327-328; M. A. Supruniuk, Stanisław L. Janikowski - człowiek od trudnych misji. Szkic do biografii autora „,Miscellanea Copernicana”, [w:] S. Janikowski, Miscellanea Copernicana, Torun 2011, s. 913; T. Krahel, Meysztowicz Walerian, [hasło w:] Stownik Polskich Teologów Katolickich 19811993, red. J. Mandziuk, wol. 8, Warszawa 1995, s. 387-390.

${ }^{22}$ W kolejności ukazywania się: L. Puciata, Grzech pierworodny w teologii św. Anzelma, Wilno 1932 (t. 1); J. Zdanowicz, Sarbiewski na tle kontrowersyj teologicznych swojego wieku, Wilno 1932 (t. 2); P. Nowicki, Wzdlużenie przedakcentowe w języku hebrajskim, Wilno 1933 (t. 3); K. Gieczys, Bractwa trzeźwości w diecezji żmudzkiej w latach 1858-1864, Wilno 1935 (t. 4); T. Sieczka, Kult obrazu N. Marji Panny Ostrobramskiej w dziejowym rozwoju, Wilno 1934 (t. 6); W. Worotyński, Seminarjum Gtówne w Wilnie: powstanie i pierwszy okres dziejów (1803-1816), Wilno 1935 (t. 7); W. Meysztowicz, Dobra kościelne jako przedmiot uprawnień w prawie W. Ks. Litewskiego, Wilno 1935 (t. 8); L. Pukianiec, Sobieski a Stolica Apostolska na tle wojny z Turcja 
Zakładając kontynuację serii wydawniczej na emigracji, ks. W. Meysztowicz musiał wziąć pod uwagę nie tylko warunki wojenne i zupełny brak współpracowników wileńskich, ale przede wszystkim niepewność co do ciągłości pracy naukowej, losów wileńskiej uczelni i studiów teologicznych w powojennej Polsce. Mimo to, w latach 1943-1947, opublikował w Watykanie kolejne cztery tomy serii (ostatni w formie powielanego rękopisu), zachowując nazwę w języku polskim i „przymocowanie” do zlikwidowanego przez Litwinów Uniwersytetu Stefana Batorego. Zachował też formę graficzną „Studiów”, format i druk, jasno-brązowy kolor okładki i rysunek godła Wydziału w jej centralnej części — kaganek wiary, płonący wśród ciemności — oraz jego dewizę non exstinguetur (nie zgaśnie). Cztery nowe tomy to:

Walerian Meysztowicz, Repertorium bibliographicum pro rebus polonicis Archivi Secreti Vaticani, Vaticani 1943 (t. 11);

Walerian Meysztowicz, De Archivo Nuntiaturae Varsaviensis quod nunc in Archivo Secreto Vaticano servantur, Vaticani 1944 (t. 12);

Petrus Savio, De actis Nuntiaturae Poloniae quae partem Archivi secretariatus status constituunt, Vaticani 1947 (t. 13);

Walerian Meysztowicz, Prospectica descriptio Archivi Secreti Vaticani (Ed. chirotipica) [Vaticani ok.1957] (t. 14) ${ }^{23}$.

Pierwsza z prac poświęcona została pamięci ks. Leona Puciaty, profesora Wydziału Teologicznego USB, zmarłego podczas okupacji niemieckiej. Zawierała krótki wstęp, w którym ks. Meysztowicz przedstawił i omówił w zarysie dotychczasowe studia polskie przeprowadzone w Archiwum Watykańskim, sięgające XVI stulecia. Autor zwrócił uwagę, że materiały dotyczące Polski przechowywane w Archivo Secreto Vaticano, mają znaczenie nie tylko dla dziejów kościoła w Polsce, ale także dla historii kościoła powszechnego oraz dla krajów graniczących z Polską.

Recenzując w 1945 roku dwa pierwsze watykańskie tomy „Studiów”, Stanisław Kościałkowski zauważył:

Oto dwie prace, niewielkie rozmiarami, ale jakże ważne w swej treści, jakże wyjątkowe miejsce zajmują one w ubogim dorobku naszych publikacji emigracyjnych, jako wydawnictwa, nie jakiekolwiek względy propagandowo-polityczne czy popularyzatorskie, lecz wyłącznie naukowe mające na celu! Już samo ogłoszenie ich drukiem w wybornej, choć łatwej do czytania łacinie, owym klasycznym esperanto naukowym Universae Reipublicae litterarum, czyni obie prace zjawiskiem zgoła wyjątkowym dzisiaj, przeznaczonym nie dla wszystkich. Przez sam fakt jednak swego ukazania się w formie, dostępnej międzynarodowemu forum badaczy, lepiej, niż wiele publikacji innych, świadczy o żywotności kultury naszej i swym ciężarem gatunkowym w gruncie rzeczy nie tylko nauce, ale sprawie polskiej poważną oddaje przysługę. [...] Wszechnica Batorowa w Wilnie wraz ze swoim Wydziałem Teologicznym po raz drugi w dziejach istnieć przestała 15 grudnia 1939 roku, ustępując miejsca innej, obcej z tradycji i ducha instytucji. Jednak dzięki ks. prof. Meysztowiczowi nie zgasła świetlana tradycja Uniwersytetu Stefana Batorego i jego Teologii, wbrew wszystkim i wszystkiemu, dając znać o sobie z Wiecznego Miasta ${ }^{24}$.

We wstępie do tomu trzynastego „Studiów”, ich wydawca napisał: A belli initio, ex quo „Studia Theologica” Universitatis Bathoreae Vilnensis, e Vilna exsules, Romae

(1683-1684), Wilno 1937 (t. 9); W. Worotyński, Seminarjum Główne w Wilnie: drugi okres dziejów i zniesienie (1816-1833), Wilno 1938 (t. 10).

${ }^{23}$ Wiadomość o tomie 14. „Studiów” znajduje się w zapowiedzi na czwartej stronie okładki „Antemurale” 1954 wol. 1 oraz jako wydany m.in. na okładce wol. 4 z 1958.

${ }^{24}$ S. Kościałkowski, Nie zgaśnie..., Orzeł Biały 1945 nr 40 (175), s. 2-3. 
eduntur, hoc tertium est volumen a nobis in lucem datum. Wiktor Sukiennicki, rok później, przywołując dorobek edytorski „Studiów”, nazwał go antycypowaniem powołania Społeczności Akademickiej i wypełnieniem najważniejszego punktu jej statutu, tj. zaświadczanie przed światem, „że wbrew pozorom Wszechnica Batorowa nadal istnieje i w granicach możliwości rozwija swą działalność naukową i kulturalną"25. Na tę ciągłość nie tylko symboliczną, ale faktyczną, potwierdzoną publikacjami pod szyldem USB, zwrócił również uwagę recenzent „Studiów” Walerian Charkiewicz, dodając, że ks. Meysztowicz wznowił serię za własne pieniądze. Charkiewicz napisał:

\begin{abstract}
Dziś Uniwersytet Stefana Batorego znów jest nieczynny. Jego kontynuacją jest Uniwersytet im. Kopernika w Toruniu, ale znaczna gromada profesorów wileńskich zasiliła Uniwersytet w Łodzi. Nowe warunki wysunęły nowe zadania, narzuciły nowe formy pracy. Gdzie jest wileńska Humanistyka z „Ateneum Wileńskiem”, z „Pracami Polonistycznymi”, z „Alma Mater Vilnensis”?... Gdzie jest wileńskie Prawo, wileńska Przyroda, wileńska Medycyna i t.d.?... Trzeba mieć wprawne oko i czujne serce, aby dostrzec nurt wileński w ogólnym nurcie współczesnej Polski, której wróg narzucił kształty, przeciwne polskiej naturze. Jeden wszakże wydział jest widoczny - Wydział Teologiczny Uniwersytetu Stefana Batorego. Ten Wydział pracuje, walczy, trwa... [...] Zespół wileńskich teologów: profesorów i zastępców USB, z ks. dziekanem prof. dr. Czesławem Falkowskim na czele pracuje jednak dalej w ramach Seminarium Metropolitalnego w Białymstoku; - wydawane są nadal „Studia Teologiczne”... Ale już poza granicami Polski [...] Wydział Teologiczny Uniwersytetu Stefana Batorego, który trwa i walczy wysiłkiem swych profesorów i uczniów, daje świetny przykład zbiorowego działania ludzi, mających jedno serce i jedną wolę, — czyste, szlachetne serce i niezłomną, nieugiętą wolę ${ }^{26}$.
\end{abstract}

Omawiając trzy emigracyjne tomy „Studiów Teologicznych”, Walerian Charkiewicz pokusił się o scharakteryzowanie działalności ks. W. Meysztowicza. Przypomnijmy, że tekst ukazał się w 1948 roku:

Praca ks. profesora Waleriana Meysztowicza jest czynem narodowym i kulturalnym wielkiej wagi. Jest to najszlachetniej pojęta walka o wolność polskiej myśli i polskiego ducha. Jest to budowanie w okresie największej burzy, która niszczy lub chce zniszczyć wszystko, co stoi na fundamentach chrześcijańskiej kultury. Jest to wreszcie najbardziej wzniosły i bezbłędny program działania Polaków na emigracji: gdy Kraj jest w niewoli, trzeba mu dopomóc, biorąc na siebie ciężar walki choćby na najmniejszym odcinku, i ponosząc trudy, za które nagrodą będzie poczucie spełnionego obowiązku ${ }^{27}$.

Nietrudno dostrzec, że tematyka trzech watykańskich tomów serii była różna od wcześniejszych publikacji. Wydawnictwa wileńskie były dysertacjami akademickimi, tymczasem nowe książki, opracowane już w Watykanie, poświęcone zostały omówieniu źródeł do dziejów kościoła katolickiego w Polsce, znajdujących się w Archivo Secreto Vaticano. Wydaje się, że już w tym okresie ks. Meysztowicz zmierzał do powołania seryjnego wydawnictwa źródłowego, które udało mu się zrealizować w 1960 roku w postaci „Elementa ad fontium editiones”.

Do roku 1944 ks. W. Meysztowicz mógł liczyć jedynie na pomoc przyjaciół z Ambasady i polskich księży przebywających na terenie Państwa Watykańskiego. Wraz z wyzwoleniem Włoch i rozlokowaniem na terenie półwyspu wojska polskiego oraz

${ }^{25}$ W. Sukiennicki, Społeczność Akademicka USB, Alma Mater Vilnensis. Prace Społeczności Akademickiej Uniwersytetu Stefana Batorego na obczyźnie [t. 1], Londyn 1949, s. 19.

${ }^{26}$ W. Charkiewicz, Non extinguetur, Lwów i Wilno 1948 nr 69, s. 2.

${ }^{27}$ Tamże. 
agend cywilnych Rządu RP na uchodźstwie, do Rzymu przyjechało wiele osób oddelegowanych z oddziałów 2. Polskiego Korpusu, zwolnionych z obozów jenieckich oraz uciekinierów z Polski. Przybywała także młodzież. W krótkim okresie powojennym, pomiędzy kapitulacją Włoch a ewakuacją polskich oddziałów wojskowych i w większej części zaplecza cywilnego 2. Korpusu, na uniwersytetach i politechnikach włoskich, głównie w Rzymie, podjęło studia akademickie blisko 1350 studentów polskich. Studenci byli żołnierzami, odkomenderowanymi na studia przez władze wojskowe (podobnie jak działo się to np. w Libanie). Opiekę nad studentami sprawował Wydział Oświaty 2. Korpusu, na którego czele stał płk prof. dr Jerzy Alexandrowicz związany z USB. Z jego inicjatywy, dla studentów Wydziału Humanistycznego Uniwersytetu w Rzymie, zorganizowane zostały przez prof. Henryka Paszkiewicza wykłady z zakresu kultury polskiej. Studium organizowało zajęcia dla około trzydziestu studentów oraz wolnych słuchaczy, w polskich ośrodkach i mieszkaniach prywatnych. Wykładali i prowadzili seminaria na nim: Karolina Lanckorońska (historia sztuki polskiej), prof. dr Giovanni Maver (literatura polska), prof. ks. dr W. Meysztowicz (historia Kościoła w Polsce) i prof. dr Henryk Paszkiewicz (historia Polski). Studia studentów polskich w wyższych szkołach włoskich zostały przerwane jesienią 1946 roku, z chwilą przeniesienia wojska do Wielkiej Brytanii. Jedynie około 180 studentom, mającym jeszcze jeden rok do ukończenia studiów, zezwoliły władze wojskowe brytyjskie pozostać na miejscu, zapewniając im pomoc materialnąa ${ }^{28}$. Ks. Meysztowicz był nie tylko członkiem zespołu, który opiekował się studentami polskimi w Rzymie, ale też organizatorem ich pobytu i bytu, w ciężkim okresie powojennym. Podlegali mu studenci prawa, dla których urządzał w swoim domu seminaria z prawa kanonicznego, karnego i cywilnego ${ }^{29}$.

Wśród uchodźców, którzy znaleźli się na Półwyspie Apenińskim, w większej części byli żołnierze i cywile zamieszkali przed wojną na terenach polskich ziem wschodnich, we Lwowie i Wilnie, którzy przeszli przez sowieckie łagry i zsyłkę. Oni też w początkach roku 1945 utworzyli w Rzymie Związek Ziem Wschodnich, jako ekspozyturę stowarzyszenia działającego od 1942 roku w Wielkiej Brytanii, w postaci dwóch związków: północno- i południowo-wschodnich. Na terenie Włoch, pomimo wielkiej liczby Polaków, powstał jeden wspólny oddział „Włochy"30. W okresie największego rozwoju oba związki posiadały 60 delegatur i kół na całym świecie i liczyły ok. 34 tys. członków ${ }^{31}$. Związany w Wilnem, ks. Walerian Meysztowicz był jednym z założycieli włoskiego oddziału Związku i sygnatariuszem wszystkich jego dokumentów. Wszedł również do pierwszego Zarządu $^{32}$, a kiedy w wyniku konferencji jałtańskiej stało się jasne, że granica Polski będzie biegła wzdłuż linii Curzona, miał wraz ambasadorem K. Papée i przyjaciółmi, m.in. Stanisławem Janikowskim, przedstawicielem rządu przy Kwirynale, zaoferować gen. Władysławowi Andersowi poparcie dla działań zmierzających do odzyskania przez Polskę niepodległości i wypowiedzenia posłuszeństwa dowództwu brytyjskiemu ${ }^{33}$. Każ-

${ }^{28}$ T. Sulimirski, Nauka polska na obczyźnie 1939-1954 (Zarys historyczny), Nauka Polska na Obczyźnie 1955 z. 1, s. 9; A. Supruniuk, Jerzy Aleksandrowicz (1886-1970), Archiwum Emigracji. Studia - Szkice - Dokumenty 2010 z. 1-2 (12-13), s. 317-321; Polscy studenciżotnierze we Włoszech 1945-1947, oprac. R. Lewicki, Londyn 1996, s. 38.

${ }^{29}$ E. Szczepanik, Opowieść o młodości i wojnie, Italii i Anglii, [w:] Świadectwa / Testimonianze, t. 1: W walce o niepodległość. Rozmowy E. Prządki z Polakami we Włoszech, Rzym 2000, s. 88.

${ }^{30}$ P. Gotowiecki, Działalność żolnierzy II Korpusu Polskiego, s. 79.

${ }^{31}$ P. Wójtowicz, Działalność Związów Ziem Wschodnich, s. 510.

${ }^{32}$ P. Gotowiecki, Działalność żolnierzy II Korpusu Polskiego, s. 80.

${ }^{33}$ W. Meysztowicz, Gawędy o czasach i ludziach, s. 347. 
de publiczne zebranie Związku odbywało się z udziałem ks. Meysztowicza, który często zabierał głos. Był wielbicielem - jak wspominał Edward Szczepanik — idei jagiellońskiej marszałka Józefa Piłsudskiego, a po wojnie związał się z gronem osób propagujących ideę Międzymorza ${ }^{34}$.

Należy odnotować jeszcze, że w latach 1945-1946 ks. Meysztowicz wydawał po włosku codzienny biuletyn „Foglietti Verdi”, przeznaczony najpewniej dla mieszkańców Rzymu ${ }^{35}$. Był też prezesem Komitetu Opieki nad Uchodźcami we Włoszech ${ }^{36}$.

Przede wszystkim jednak Meysztowicz był naukowcem i potrzeba prowadzenia badań naukowych determinowała wszystkie jego działania organizacyjne w Rzymie. W latach wojny opublikował w Watykanie dwie rozprawy historyczne: Elisabeth de Pologne, reine de Hongrie, pour le sixieme centenaire de son pelerinage a Rome 13431943 (1943) oraz L'Eglise catholique de Pologne entre les deux guerres 1919-1939 (1944). Przygotował także rozdział o kościele katolickim do trzytomowego wydawnictwa szwajcarskiego Pologne 1919-1939, wydanego w Neuchatel w 1946 roku. Uzyskał tym samym pozycję wybitnego znawcy dziejów średniowiecza oraz historii Kościoła w Polsce i Europie Wschodniej.

10 listopada 1945 roku, powodowani optymizmem wielkiej liczby Polaków na ziemi włoskiej i związanego $\mathrm{z}$ tym zainteresowania badaniami nad znajdującymi się w archiwach włoskich dokumentami do przeszłości Polski, ks. W. Meysztowicz, Karolina Lanckorońska, Stanisław Biegański, hr. Józef Michałowski i Henryk Paszkiewicz, na spotkaniu w rzymskiej Bibliotece Polskiej Akademii Umiejętności, powołali do życia Polski Instytut Historyczny w Rzymie, z siedzibą przy Via degli Scipioni $284^{37}$. Właściwym twórcą Instytutu był jednak ks. Meysztowicz ${ }^{38}$. Na sprawczą rolę Meysztowicza w organizacji PIH zwróciła uwagę K. Lanckorońska ${ }^{39}$. Również autorka krótkiego zarysu historii PIH $^{40}$. Zadaniem nowej placówki badawczej miało być wspieranie studiów źródłoznawczych na terenie Italii, praca badawcza i wydawnicza, choć w pierwszym okresie wydawało się, że istnieje również możliwość prowadzenia rozwiniętej działalności odczytowej, konferencyjnej i skierowanej na współpracę międzynarodową. Świadectwem takiego myślenia są spisy wykładów notowane w biuletynie oraz w kolejnych zeszytach „Antemurale" ${ }^{\text {"41 }}$. Generalnie, tematyka podejmowanych

34 [E. Szczepanik] E.S., „Ksiądz Prałat”. Wspomnienie o księdzu infułacie Meysztowiczu, Rzeczpospolita $1982 \mathrm{nr} 5$ (321) s. 4

${ }^{35}$ J. Kowalik, Bibliografia czasopism polskich wydawanych poza granicami Kraju od września 1939 roku, t. 1: A-J, Lublin 1976, s. 173. Zob. też: tenże, Czasopiśmiennictwo, [w:] Literatura polska na obczyźnie 1940-1960, red. T. Terlecki, t. 2, Londyn 1965, s. 385.

${ }^{36}$ E. Szczepanik, Opowieść o młodości $i$ wojnie, Italii i Anglii, [w:] Śsiadectwa / Testimonianze, t. 1, s. 249; tenże, Ksiadz Prałat, [w:] Świadectwa / Testimonianze, t. 4: Pro publico bono. Polityczna, spoleczna i kulturalna działalność Polaków w Rzymie w XX wieku, Rzym 2006, s. 116-118.

${ }^{37}$ Później siedzibę przeniesiono na via Virginio Orsini 19.

${ }^{38} \mathrm{Na}$ decydującą rolę W. Meysztowicza zwróciła uwagę Karolina Lanckorońska we wspomnieniu pośmiertnym: K. Lanckoronska, Walerian Meysztowicz (1893-1982), Antemurale 1982-1983 wol. 26, s. 220.

${ }^{39}$ Taż, Wspomnienie o Księdzu Walerianie Meysztowiczu, [w:] Świadectwa / Testimonianze, t. 4 , s. 110.

${ }^{40}$ Polski Instytut Historyczny w Rzymie, oprac. A. Kwiatkowska, [w:] Świadectwa / Testimonianze, t. 4, s. 137-148.

${ }^{41}$ Por. np.: W. Meysztowicz, De Instituto Historico Polonico deque eiusdem praesenti editione, Antemurale 1954 wol. 1, s. 6-7. 
badań, spotkań i publikacji związana była z zainteresowaniami badawczymi pracowników Instytutu. Niektóre wykłady, spotkania i konferencje organizowane były poza Instytutem i gromadziły międzynarodowe gremia historyków; w większej części jednak, członkami Instytutu byli polscy naukowcy mieszkający i pracujący we Włoszech. Ks. Meysztowicz był od początku, aż do roku 1981, prezesem PIH, a następnie, przez rok, aż do śmierci w maju 1982 roku, prezesem honorowym ${ }^{42}$.

Pierwszym własnym wydawnictwem Instytutu był powielany w języku łacińskim nieregularny biuletyn „Relationes Instituti Historici Polonici Romae”, w którym na bieżąco informowano o wydarzeniach naukowych - konferencjach, odczytach, wydawnictwach — streszczając najważniejsze tezy referatów ${ }^{43}$. W nagłówku biuletynu zamieszczono znak-symbol Instytutu oraz jego dewizę: Non exstinguetur (Nigdy nie zgaśnie). Zarówno symbol - lampka oliwna wisząca na łańcuchu — jak i dewiza, zostały skopiowane z symboliki Wydziału Teologicznego USB (wg projektu Ferdynanda Ruszczyca), co dodatkowo podkreślało pewną symboliczną ciągłość zlikwidowanej uczelni, z której wywodził się ks. Meysztowicz ${ }^{44}$.

W roku 1954 Instytut rozpoczął wydawanie czasopisma naukowego „Antemurale”. Zarząd PIH stanowili wówczas: ks. Meysztowicz — prezes, ks. Józef Warszawski i Piotr Naruszewicz - wiceprezesi, Stanisław Jezierski — sekretarz oraz Władysław Kujawski — redaktor wydawnictw. Na okładce pierwszego tomu „Antemurale” znalazł się symbol PIH - symbol Wydziału Teologicznego USB, ze zmienioną nieco dewizą: non extinguetur. W kolejnych zeszytach dewiza miała już pierwotną wersję. Zawartość treści „Antemurale” ukazuje niezwykłą różnorodność podejmowanych w Instytucie tematów. Przeważały tematy związane z historią Rzeczypospolitej i jej związków ze światem chrześcijańskim od wczesnego średniowiecza do XIX stulecia. Studia poświęcone historii nowszej: XIX i XX wieku oraz zagadnieniom innym niż historyczne (językoznawstwo, filozofia, kultura) były rzadsze. Ks. Meysztowicz dążył do związania bliższych kontaktów pomiędzy PIH i Polskim Towarzystwem Naukowym na Obczyźnie, którego był członkiem, i kiedy w początkach lat 60., wobec trudności finansowych, Towarzystwo nie było w stanie publikować prac swoich członków, otworzył dla nich łamy „Antemurale”, finansowanego przez Fundację z Brzezia Lanckorońskich. W znacznym stopniu poszerzyło to treść czasopisma i umożliwiło publikację literaturoznawcom. Dziesiąty tom „Antemurale” z 1966 roku w całości wypełniły prace polonistyczne dostarczone przez PTNO $^{45}$. Oznaczało to jednak utratę pewnej niezależności. Czasopismo mimo to było miejscem szczegółowego opisu działalności Instytutu, nawet wówczas, gdy wydawane było wspólnie z PTNO. Redakcja, której przewodniczył ks. Meysztowicz, potrafiła zainteresować swoją tematyką również badaczy niepolskich, którzy autorsko wspierali szczupłe grono pracowników Instytutu. „Antemurale” ukazywało się do śmierci założyciela i redaktora; ostatnie dwa tomy: XXVI i XXVIIXXVIII wyszły niedługo po jego śmierci, w latach 1983 i 1985.

${ }^{42}$ M. B. Topolska, Organizacje naukowe poza W. Brytania, [w:] Mobilizacja uchodźstwa do walki politycznej 1945-1990, praca zbiorowa, red. L. Kliszewicz, Londyn 1995, s. 493-497. Skład Zarządu PIH podawany był w „Antemurale” (od 1954), a także co roku w „Roczniku Polskiego Towarzystwa Naukowego na Obczyźnie” (od 1952), ukazującym się w Londynie.; zamieszczał go także „Rocznik Polonii”.

43 J. Kowalik, Czasopiśmiennictwo, s. 444.

${ }^{44}$ Zob.: A. Supruniuk, M. A. Supruniuk, Uniwersytet Stefana Batorego $w$ Wilnie $w$ fotografiach 1919-1939, s. XX — tam fotografia łańcucha rektorskiego z symbolami wydziałów.

45 S. Portalski, Zarys historii Polskiego Towarzystwa Naukowego na Obczyźnie, Londyn 2009, s. 162. 
Zebrana wiedza na temat zawartości archiwów oraz bibliotek włoskich i europejskich pozwoliła Instytutowi rozpocząć planowanie wydawnictwa czysto źródłowego. W 1956 roku na forum PIH ks. Meysztowicz wygłosił referat „O sprawie wydawania poloników znalezionych za granicą,46. Cztery lata później, w 1960 roku, Instytut zainicjował serię źródłową „Elementa ad fontium editiones”, w której kolejnych wydawnictwach publikowane były nieznane źródła historyczne do dziejów ziem polskich od średniowiecza po wiek XVIII, odnajdywane w archiwach i bibliotekach europejskich. Podobnie jak inne wydawnictwa PIH, także „Elementa” ozdobione zostały godłem i dewizą, symbolicznie podkreślającą ciągłość wydawnictw Wydziału Teologicznego USB. Tom pierwszy zawierał Polonica ex libris ,,Obligationum et solutinum” Camerae apostolice $a b$ A. 1373, w opracowaniu Jana Lisowskiego; drugi publikował „Liber disparata antiqua continens". Alexandro Masoviensi episcopo Tridentino dicatus, w opracowaniu Edmunda Winklera. W kolejnych tomach udostępniono czytelnikom źródła do dziejów Rzeczypospolitej znajdujące się w archiwach włoskich: w Watykanie, Trydencie, Parmie, Brisighella, Aquili, Florencji oraz w Wielkiej Brytanii (British Museum), Hiszpanii (Archiwum Narodowe), Danii (Archiwum Królewskie) i w ostatnich latach przede wszystkim w Niemczech, gdzie w Berlinie przechowywane są dawne archiwa z Królewca.

Również w 1954 roku zaczął się ukazywać w Rzymie rocznik „Sacrum Poloniae Millennium. Rozprawy - szkice - materiały historyczne”, publikujący teksty także w języku polskim. Wydawcą rocznika był Komitet Rzymski pod przewodnictwem biskupa Józefa Gawliny, lecz wśród autorów znaleźli się członkowie PIH. Tematyka „Sacrum Poloniae” była nieco szersza niż w „Antemurale” i obejmowała zagadnienia teologiczne, historyczne i literackie; te ostatnie wyłącznie w kontekście religijnym. Chronologicznie tematyka dotyczyła okresu od średniowiecza po połowę wieku XX. Ukazało się dwanaście tomów rocznika, ostatni w 1966 roku zawierał zbiorczą bibliografię zawartości. Ks. W. Meysztowicz był nie tylko autorem kilku szkiców zamieszczonych w „Sacrum” w języku polskim, ale przede wszystkim kierował redakcją wydawnictwa.

Założeniem Polskiego Instytutu Historycznego w Rzymie było rozwijanie wiedzy o Polsce i jej wymiana w międzynarodowej przestrzeni naukowej. Jego pracownicy i współpracownicy byli często zatrudnieni w wyższych uczelniach, instytutach naukowych (włoskich, niemieckich, brytyjskich, francuskich i szwajcarskich) i należeli to towarzystw zrzeszających ludzi nauki. Ks. W. Meysztowicz od 1950 roku udzielał się w polskich i polsko-brytyjskich instytucjach naukowych powstałych na emigracji; został czynnym członkiem zamiejscowym Wydziału Humanistycznego powstałego wówczas w Londynie Polskiego Towarzystwa Naukowego na Obczyźnie ${ }^{47}$. Brał udział w jego pracach, publikacjach i wydarzeniach kongresowych, w szczególności w antologii poświęconej Adamowi Mickiewiczowi ${ }^{48}$ oraz zorganizowanym w roku 1970 Kongresie Nauki i Kultury Polskiej na Obczyźnie, który odbył się w 20. rocznicę powstania $\mathrm{PTNO}^{49}$.

${ }^{46}$ Przegląd działalności naukowej towarzystw naukowych i instytucji, oraz innych placówek polskich na obczyźnie 1956-1957, Rocznik Polskiego Towarzystwa Naukowego na Obczyźnie 1956-1957, Londyn 1957, s. 127-128.

${ }^{47}$ S. Portalski, Zarys historii Polskiego Towarzystwa Naukowego na Obczyźnie, s. 21.

${ }^{48}$ Adam Mickiewicz. Księga w stulecie zgonu (1855-1955), Londyn 1958.

${ }^{49}$ S. Portalski, Zarys historii Polskiego Towarzystwa Naukowego na Obczyźnie, s. 163. 


\section{Międzynarodowy Kongres Historyków w Rzymie}

Najważniejszym wydarzeniem naukowym z udziałem Polskiego Instytutu Historycznego w pierwszym dziesięcioleciu działalności był X Międzynarodowy Kongres Historyków, który odbył się w Rzymie 2-11 września 1955 roku. Polscy historycy $\mathrm{z}$ emigracji brali udział $\mathrm{w}$ paryskim, IX Kongresie, ale dopiero udział w organizacji wydarzenia rzymskiego ukazał wielkie możliwości organizacyjne i zaplecze naukowe polskiej emigracji. Instytutowi przypadł obowiązek zorganizowania udziału polskich historyków z uchodźstwa. Jeszcze w roku 1954 z upoważnienia Polskiego Towarzystwa Historycznego PIH reprezentował sprawy historyków wobec Comité International des Sciences Historiques w Paryżu oraz Giunta Centrale per gli Studi Storici w Rzymie. Najważniejszą przeszkodą było przekonanie organizatorów, że nauka polska na emigracji stanowi istotny fragment dorobku naukowego historyków polskich, oraz doprowadzenie do oficjalnego zaproszenia ich do udziału w Kongresie. Comité International uznał oficjalny charakter delegatów PTH na Obczyźnie i przydzielił im siedem komunikatów. Nie wszyscy zaproszeni wzięli udział w Kongresie; referaty wygłosili: Oskar Halecki („Rome and the Eastern Europe after the Council of Trest”), Leon Koczy (,The Holy Roman Empire and Poland”), Marian Kukiel („Problème des guerres d'insurrection au XIX siècle”) i ks. W. Meysztowicz („Les duchess de Turov et l'union de l'église ruthène avec Rome au XI siècle") ${ }^{50}$. Ponadto w Kongresie uczestniczyli: Wacław Lednicki z Uniwersytetu Kalifornijskiego, Jakub Sobieski z Brukseli ${ }^{51}$ oraz Władysław Kujawski z PIH w Rzymie ${ }^{52}$. Oprócz referatów, polscy uczestnicy zgłosili 22 interwencje w dyskusjach plenarnych. Dla polskich referentów i uczestników Kongresu Instytut wydał osobny, specjalny zeszyt „Relationes”, w którym zamieszczono wykaz odczytów polskich oraz dotyczących Polski, adresy w Rzymie i niezbędne informacje. W dniu otwarcia Kongresu ukazał się ponadto drugi tom „Antemurale", zawierający pełne teksty referatów uczestników Kongresu: Haleckiego, Koczego, Kukiela i Meysztowicza, a także szkice: J. Jasnowskiego: Problems of the Frontiers with the Steppes of the North Black Sea, L. Koczego: Compte-rendu of H. Paszkiewicz „The Origin of Russia”, odnaleziony i przygotowany do druku przez ks. W. Meysztowicza Manuscriptum Gertrudae filiae Mesconis II Regis Poloniae oraz sprawozdanie z działalności PIH w latach 1954/1955. Tom został wręczony papieżowi Piusowi XII w czasie uroczystej audiencji dla uczestników Kongresu oraz zaprezentowany na sesji plenarnej w dzień otwarcia Kongresu.

Instytut przygotował ponadto wystawę polskiej książki historycznej na emigracji, przede wszystkim książek napisanych przez członków Polskiego Towarzystwa Historycznego na Obczyźnie, która weszła w skład powszechnej kongresowej wystawy książki historycznej z lat 1945-1955. Na dwóch polskich stoiskach zaprezentowano 133 pozycje. Wystawie towarzyszył, wydany przez Instytut, katalog wystawianych

${ }^{50}$ Przegląd działalności naukowej towarzystw naukowych i instytucji, oraz innych placówek polskich na obczyźnie 1955-1956, Rocznik Polskiego Towarzystwa Naukowego na Obczyźnie 1955-1956, Londyn 1956, s. 123.

${ }^{51}$ Pracownik Polskiego Instytutu Naukowego w Belgii, autor Jean de Pologne à Louvain, 1253. - Note historique en marge des relations flamando-polonaises an Moyen Age, Bruxelles 1950.

${ }^{52}$ De parte quam Societas Polonica Historica in Exteris in X Congressu Internationali Scientiarum Historicarum Romae diebus 2-11 sept. 1955 habuti, Antemurale 1956 wol. 3, s. 151-153. 
książek Elenchus operum quae a Societate Historica Polonica in exteris exhibita sunt in X. Congressu Internationali Scientiarum Historicarum Romae ${ }^{53}$.

Rzymski Instytut brał udział również w organizacji kolejnego Kongresu, który w 1960 roku odbył się w Sztokholmie, lecz już bez równie licznego polskiego udzia$\mathrm{\jmath u}^{54}$. Zaznaczyć należy, że współpracownicy PIH czynnie brali udział we wszystkich kolejnych międzynarodowych wydarzeniach kongresowych.

\section{Społeczność Akademicka USB w Londynie}

Pomysł powołania stowarzyszenia, które jednoczyłoby rozsypanych po świecie ekspatriantów, pracowników naukowych, absolwentów i studentów zlikwidowanego w 1939 roku Uniwersytetu w Wilnie, a jednocześnie tworzyło symboliczną ciągłość tradycji zlikwidowanej wileńskiej uczelni, wysunął profesor Wiktor Sukiennicki na londyńskim zebraniu profesorów i absolwentów USB w początkach 1947 roku. Powoływał się przy tym na ideę, że uniwersytety tworzą ludzie, a nie budynki. Miał powiedzieć:

Można zniszczyć instytucję, zlikwidować zakład, rozgrabić lub zrabować bibliotekę, czy pracownię, lecz ludzi można tylko zabić. Dopóki żyją, więź zadzierzgnięta trwa. I skoro oni tam w kraju nie mają możności swobodnego ujawniania swych myśli i uczuć, obowiązkiem naszym, przebywających w wolnym świecie, jest tę prawdę ujawnic ${ }^{55}$

Stowarzyszenie, właściwie quasi-uniwersytet, pod nazwą Społeczność Akademicka USB w Londynie, powstało w końcu 1947 roku, a od 1948 rozpoczęło działalność odczytową i organizacyjną. Powołano władze zastępcze USB pod nazwą Rady Społeczności Akademickiej, na czele której stanął Senior Społeczności — jako jej Rektor. Seniorem miał być każdorazowo najstarszy wiekiem profesor. Pierwszym został w 1947 roku, jeden z najwybitniejszych historyków, prof. Stanisław Kościałkowski, przebywający wówczas jeszcze (do 1950) w Bejrucie. We władzach znaleźli się także $\mathrm{z}$ racji posiadania tytułu profesora lub docenta USB: prof. dr Cezaria Baudouin de Courtenay Ehrenkreutzowa Jędrzejewiczowa, prof. Zygmunt Jundziłł ${ }^{56}$, prof. Wiktor Sukiennicki, prof. Stanisław Swianiewicz i doc. dr Władysław Wielhorski. Stanowisko Seniora było dożywotnie. W 1960 roku, po śmierci prof. Kościałkowskiego, objęła je

${ }^{53}$ Przeglad działalności naukowej towarzystw naukowych i instytucji, oraz innych placówek polskich na obczyźnie 1955-1956, Rocznik Polskiego Towarzystwa Naukowego na Obczyźnie 1955-1956, Londyn 1956, s. 123-124.

${ }^{54}$ Przeglad działalności naukowej towarzystw naukowych i instytucji, oraz innych placówek polskich na obczyźnie 1956-1957, Rocznik Polskiego Towarzystwa Naukowego na Obczyźnie 1956-1957, Londyn 1957, s. 128.

${ }^{55}$ B. Podoski, Dzieje Społeczności Akademickiej Uniwersytetu Stefana Batorego, Kwartalnik Kresowy 1987 z. 117-120, s. 19; to samo A. Blum, Spoleczność Akademicka USB, Dziennik Polski i Dziennik Żołnierza (Londyn) 19.10.1987; przedruk w: Kwartalnik Kresowy 1987, z. 117-120, s. 15-17. W szkicu M. B. Topolskiej znajduje się informacja, że pierwsze spotkania grona uczniów i profesorów USB miały miejsce już w 1941 roku; wiadomości tej nie udało się potwierdzić - M. B. Piechowiak-Topolska, „,Wilno w Londynie”. Dzieje Uniwersytetu Stefana Batorego na emigracji po II wojnie światowej, [w:] Nauka polska na obczyźnie. Stan i perspektywy badawcze, red. W. Hładkiewicz, M. Szczerbiński, Gorzów Wielkopolski 2000, s. 51.

${ }^{56}$ Zygmunt Jundziłł (1880-1953), adwokat, prawnik, historyk; absolwent prawa — doktorat na USB w Wilnie (1925); zob.: S. Kościałkowski, Ś.P. Zygmunt Jundziłt, Alma Mater Vilnensis. Prace Społeczności Akademickiej Uniwersytetu Stefana Batorego na obczyźnie [t. 3], Londyn 1953, s. 386. 
Cezaria Jędrzejewiczowa, a po niej w 1967 roku ks. prof. Walerian Meysztowicz. Ostatnim Seniorem i prezesem Rady Naukowej był prof. Stanisław Swianiewicz. Społeczność została rozwiązana w 1983 roku. Ks. Meysztowicz kierował stowarzyszeniem przez kilkanaście lat. Z racji stałego pobytu w Rzymie mógł pełnić swoją funkcję jedynie korespondencyjnie, z rzadka odwiedzając Londyn, lecz fakt ten nie wpływał na rozwój instytucji. Rola stowarzyszenia w większym stopniu ograniczała się w tym okresie do manifestowania przynależności i pielęgnowania pamięci o Wielkim Księstwie Litewskim i Uniwersytecie w Wilnie, co było bliskie zainteresowaniom naukowym Meysztowicza. Wiek oraz zajęcia naukowe uniemożliwiły Seniorowi wziąć udział również w uroczystościach roku akademickiego 1969/1970 Społeczności, które odbyły się 11 października 1969 roku, dokładnie co do dnia w 50. rocznicę powołania Uniwersytetu Stefana Batorego. Słowo wstępne nieobecnego na uroczystościach Seniora, ks. prof. W. Meysztowicza, odczytał Tadeusz Kiersnowski, który w latach 1919-1920 sprawował w Wilnie funkcję prezesa Rady Młodzieży. Nie wziął też udziału ks. Meysztowicz w uroczyście obchodzonym 25-leciu Społeczności w 1973 roku, które odbyło się z udziałem Prezydenta RP Stanisława Ostrowskiego, ambasadora Edwarda Raczyńskiego, członków Rządu, Rektora T. Sulimirskiego i profesury PUNO oraz grona przyjaciół. Tym razem tekst zagajenia Seniora, nadesłany z Rzymu, odczytał Bohdan Podoski $^{57}$. Najważniejszym wydarzeniem, którym Społeczność corocznie zaznaczała swoją obecność w Londynie, były Inauguracje Akademickie (na wzór inauguracji w Wilnie) oraz związany z nimi Wykład Inauguracyjny. W latach 1948-1981 wygłosiło wykłady ponad 20 naukowców, w tym głównie historycy pochodzący z Wilna. Wśród nich: S. Kościałkowski: „Marian Zdziechowski jako uczony, myśliciel i człowiek"58; S. Swianiewicz: „Wschód i Zachód w rozwoju gospodarczym”, ${ }^{59}$; W. Wielhorski: Wielkie Księstwo Litewskie w świetle kultury zachodniej" "60; Marian Bohusz-Szyszko: „Sztuka polska na tle XIX stulecia” ${ }^{\text {61 }}$; Bohdan Podoski: „Dzieje Uniwersytetu Wileńskiego"62; Kazimierz Okulicz: „Epilog heroicznego okresu 1920-1922”,63; Aleksander Blum: „Bitwa pod Piotrkowem i jej znaczenie” ${ }^{64}$ czy Zdzisław S. Siemaszko: „Wileń-

${ }^{57}$ S. P., Inauguracja Roku Akad. 1973-4 Wszechnicy Batorowej, Kwartalnik Kresowy 1974 z. 70,71 , s. $48-49$.

58 Pełen tekst wykładu: S. Kościałkowski, Marian Zdziechowski jako uczony, myśliciel i człowiek, [w:] tegoż, Studia i szkice przygodne z historii i z jej pogranicza z literatura, Londyn 1956, s. 136-151. W zmienionej nieco wersji tekst ukazał się po francusku w „Antemurale” (1956, wol. 3).

${ }_{59}$ B. Podoski, Dzieje Społeczności Akademickiej Uniwersytetu Stefana Batorego, s. 33; Pełen tekst wykładu: S. Swianiewicz, Wschód i Zachód w rozwoju gospodarczym, Kultura $1953 \mathrm{nr}$ 2-3 (64-65), s. 15-26.

${ }^{60}$ B. Podoski, Dzieje Społeczności Akademickiej Uniwersytetu Stefana Batorego, s. 33.

${ }^{61}$ Tamże, s. 38.

${ }^{62}$ Tamże; krótkie wspomnienie o śp. Marianie Zdziechowskim odczytał Kazimierz Okulicz, Przegląd działalności naukowej towarzystw naukowych i instytucji, oraz innych placówek polskich na obczyźnie 1964-1965, Rocznik Polskiego Towarzystwa Naukowego na Obczyźnie 1964-1965, Londyn 1965, s. 91.

${ }^{63}$ B. Podoski, Dzieje Społeczności Akademickiej Uniwersytetu Stefana Batorego, s. 38. Wykład był poświęcony dziejom tzw. Litwy Środkowej oraz losom koncepcji sfederowania całości ziem byłego Wielkiego Księstwa Litewskiego z Polską; patrz: Przegląd działalności naukowej towarzystw naukowych i instytucji, oraz innych placówek polskich na obczyźnie 1965-1966, Rocznik Polskiego Towarzystwa Naukowego na Obczyźnie 1965-1966, Londyn 1966, s. 7.

${ }^{64}$ B. Podoski, Dzieje Spoteczności Akademickiej Uniwersytetu Stefana Batorego, s. 46; Spo- 
ska burza $1944^{\prime \prime 65}$. Ks. prof. Walerian Meysztowicz wygłosił tylko jeden wykład inauguracyjny. Było to 4 września 1970 roku, a wykład nosił tytuł „Zygmunt August i Filip II"66. Niewielki był również udział ks. Meysztowicza w wydawnictwach Społeczności. W wydawanym nieperiodycznie almanachu „Alma Mater Vilnensis”, zaledwie raz ukazał się jego szkic. Na początku roku 1958 wyszedł tom piąty „AMV”, zatytułowany „Prace zebrane”. Ukazał się on, co zaznaczono we wstępie, w rocznicę 300-lecia Ugody Hadziackiej i zawierał, obok pracy prof. Kościałkowskiego Ugoda Hadziacka, wspomnienia członków Społeczności oraz szereg opracowań na temat dziejów Wielkiego Księstwa Litewskiego. Wśród autorów znaleźli się: Z. Jundziłł, C. Jędrzejewiczowa, W. Wielhorski, Zbigniew Folejewski i właśnie ks. W. Meysztowicz. Jego artykuł nosił tytuł Św. Brunon na Litwie w 1009 roku ${ }^{67}$.

W roku 1972 ukazała się książka, dla której Społeczność Akademicka była jedynie instytucją wspomagającą starania o wydanie i gromadzenie finansów. W żadnym miejscu nie została odnotowana jako wydawca. Jednak ze względu na tematykę oraz zespół autorów, z których przeważająca większość to byli pracownicy lub absolwenci USB, można ją uznać jako ostatni akcent wydawniczy Uniwersytetu Stefana Batorego na Obczyźnie, zwłaszcza, że po roku 1972 nie ukazała się już żadna książka Społeczności. Książka nosiła tytuł „Pamiętnik Wileński”, ${ }^{\text {,8 }}$. Wśród kilkunastu tekstów dotyczących Wilna, „Pamiętnik” zawierał szkice historyczne i wspomnieniowe oraz reportaże pracowników i absolwentów USB, w części również napisane wcześniej i przedrukowane, wśród nich: Waleriana Meysztowicza „Marszałek Józef Piłsudski”.

Meysztowicz wielokrotnie w swoich tekstach wspomnieniowych wracał do wileńskiej przeszłości. Z pamięci o USB powstał m.in. wnikliwy szkic Sztuka w Wilnie poświęcony niemal w całości Wydziałowi Sztuk Pięknych USB oraz liczne wspomnienia i kolegach, zamieszczone w dwóch tomach gawęd zatytułowanych Gawędy o czasach i ludziach ${ }^{69}$, dwukrotnie, lecz bez powodzenia, zgłaszanych do nagrody londyńskich „Wiadomości”, ${ }^{70}$.

W kontekście zasług ks. Waleriana Meysztowicza dla pamięci Uniwersytetu Wileńskiego należy dodać, że wraz z jego śmiercią zmalało zainteresowanie PIH sprawami Wilna i Batorowej Wszechnicy. Przygotowane w Krakowie przez ks. Ludwika Piechnika czterotomowe opracowanie Dziejów Akademii Wileńskiej od powstania do 1773 roku wydane zostało w Rzymie nie przez Polski Instytut Historyczny, ale przez Institutum Historicum Societatis Jesu w latach 1983-1990.

łeczność Akademicka Uniwersytetu Stefana Batorego, Kwartalnik Kresowy 1979 z. 88, 89, 90, 91, s. 126; Bałtycz, Marzec wileński w Londynie, Dziennik Polski i Dziennik Żołnierza, 7.04.1980.

${ }^{65}$ B. Podoski, Dzieje Społeczności Akademickiej Uniwersytetu Stefana Batorego, s. 46.

${ }^{66}$ Tamże, s. 42.

67 „Alma Mater Vilnensis”, [t. 5], Londyn 1958, s. 121-132. Józef Bujnowski, autor krytycznego szkicu na temat eseju historycznego na emigracji, zamieszczonego w pierwszym tomie Literatury polskiej na obczyźnie 1940-1960, uznał za właściwe wyróżnić ten szkic w dorobku ks. W. Meysztowicza; patrz: J. Bujnowski, Esej, [w:] Literatura polska na obczyźnie 1940-1960, t. 1, s. 238.

${ }^{68}$ Od Komitetu Redakcyjnego, [w:] Pamiętnik Wileński (Londyn-Łomianki) 2010, s. 5-6.

${ }^{69}$ W. Meysztowicz, Gawędy o czasach i ludziach, t. 1-2, Londyn 1973-1974.

70 Od Herberta do Herberta. Nagroda „Wiadomości” 1959-1990, oprac. i przedmowa S. Kossowska, Londyn 1993, s. 213, 224. 


\section{Zakończenie}

Opracowana w przyszłości bibliografia drukowanych prac ks. W. Meysztowicza odnotuje również wielką liczbę jego tekstów popularyzatorskich, drukowanych w czasopismach emigracyjnych we Włoszech, Francji i Wielkiej Brytanii. Najważniejszym miejscem druku były dla księdza profesora londyńskie „Wiadomości”. Pisał do tygodnika wydawanego przez Mieczysława Grydzewskiego już od wczesnych lat 50. Z tego pierwszego okresu może najciekawszy będzie esej Od Florencji po Brześć (1959 nr 23, s. 1), stanowiący omówienie pracy Oskara Haleckiego From Florence to Brest (14391596), który kończy wyznaniem: „Wielkie to dzieło. Nie mogłoby ono powstać w niewoli. Jest ono pomnikiem wolności, za którą się płaci wygnaniem”. Warto też zwrócić uwagę na inny artykuł recenzyjny: O książe prof. Paszkiewicza (1956 nr 40, s. 5), w którym omówił percepcję książki Henryka Paszkiewicza The Origin of Russia w Stanach Zjednoczonych i Europie, wykazując doskonałą znajomość literatury historycznej i stanu badań nad Rosją Sowiecką, a także późniejszy o pięć lat: $Z$ toporem do okna (1961 nr 48, s. 1), o podróży jezuity o. Jana Pawła Campani (Campanusa) do Moskwy w 1581 roku. Jednak na dobre współpraca z „Wiadomościami” rozpoczęła się z chwilą objęcia redakcji przez Michała Chmielowca. Liczba tekstów oraz ich poczytność pozwoliły przyznać ks. Meysztowiczowi nagrodę „za najwybitniejsze utwory ogłoszone w Wiadomościach w 1971 r."71.

Szczególnie ważna wydaje się także współpraca pisarska z londyńskim czasopismem „Życie”, wydawanym przez Katolicki Ośrodek Wydawniczy „Veritas”. Artykuły dla katolickiego tygodnika powstawały $\mathrm{z}$ reguły na marginesie lektury wydawanych na emigracji książek i czasopism, a także z konieczności podejmowania tematów aktualnych, choćby w kontekście rocznic historycznych i - co nierzadkie — z konieczności obrony Kościoła katolickiego. Czy były zamawiane - nie wiemy. Zaznaczyć należy, że „Życie” drukowało wiele podobnych szkiców historyków i publicystów katolickich tej miary co Oskar Halecki, Stanisław Kościałkowski, Marian Kukiel, Leon Koczy, Józef Jasnowski, Jan Rembieliński, Stefan Badeni czy Władysław Folkierski. Ks. Meysztowicz opublikował w „Życiu” osiem artykułów, w latach 1949-1956. Wśród nich na uwage zasługują: Położenie Kościoła w Polsce (1953 nr 36, s. 1-2, 4, 6), w którym polemizuje z opracowaniem Jana Szuldrzyńskiego w piątym „krajowym” zeszycie paryskiej „Kultury”, a de facto z retoryką wydawnictw Instytutu Literackiego w Paryżu; Watykan a Polska. Walka z progresizmem (1956 nr 8, s. 1) oraz Zagadnienia kultury (1956 nr 44, s. 9-12).

Warto również odnotować jeden tylko szkic historyczny opublikowany w paryskiej „Kulturze”: Przedlużamy historię Polski (Poselstwo Mieszka I do Abderamana III kalifa Kordoby w r. 955 (1951 nr 1, s. 36-46), wydany także w osobnej nadbitce, oraz artykuły w rzymskim „Duszpasterzu Polskim za Granicą”.

Ks. Meysztowicz napisał również przedmowę do pierwszego polskiego przekładu Małego świata Don Camilla Giovanni Guareschi, w przekładzie Jana Bielatowicza (Londyn: Veritas, 1954), w której wyrażał zastrzeżenia „,do dobrodusznych metod pomniejszania komunizmu”, jak zauważyła Zofia Kozarynowa ${ }^{72}$.

\footnotetext{
${ }^{71}$ Tamże, s. 198-199.

${ }^{72}$ Z. Kozarynowa, Przekłady z języków obcych, [w:] Literatura polska na obczyźnie 19401960 , t. 2 , s. 354
} 


\section{FATHER. PROF. WALERIAN MEYSZTOWICZ AND THE POLISH HISTORICAL INSTITUTE IN ROME}

The professors of the Polish University in Vilnius, which operated in 1919-1939, after 1945 played a major role in the Polish science during emigration. One of the professors from Vilnius was father Walerian Meysztowicz, theologian, and a publisher of primary sources. Even before the war he became a diplomatic counselor of the Polish Embassy in Vatican. During the war he resided in Vatican, and after it in Rome. In 1945 along with other Polish scholars he brought the Polish Historical Institute in Rome into existence. The Institute carried out research, organized conferences and meetings, and, most importantly, published the magazines Antemurale and a series of sources Elementa ad fontium editiones-which published documents on the history of Poland and the catholic church in Middle Europe from Italian, Spanish, French and German Archives.

Keywords: Walerian Meysztowicz; Polish Historical Institute; Antemurale; Elementa ad fontium editiones; Polish scholarship during emigration; Stefan Batory University in Vilnius. 